\title{
Интернет-технологии как инструмент продвижения туристской дестинации
}

\author{
Кедрова Е.В., аспирант, \\ ФГБОУ ВО «МГУ им. Н.П. Огарёва», \\ 2. Саранск \\ E-mail: kedrova.ev@mail.ru
}

Научный руководитель: к.2.н., доцент Кицис В.М.

В настоящее время отрасль туризма в России претерпевает значительные изменения в связи с внешними геополитическими процессами и внутренней экономической ситуацией. У российских регионов появляется уникальный шанс расширить круг потребителей собственных туристских услуг не только за счет путешественников из различных регионов России, но и иностранцев, проживающих за рубежом. В данном контексте на передний план выступает продвижение не отдельных туристских продуктов региона, а туристской дестинации в целом, под которой понимается географическая территория, обладающая определенной привлекательностью для туристов.

Термин «продвижение» по отношению к территории как объекту продвижения следует рассматривать как совокупность мероприятий по информированию потенциальных потребителей о туристском потенциале региона через различные информационные каналы и средства связи и стимулированию у них потребности в приобретении регионального туристского продукта.

Продвижение туристской дестинации возможно через различные маркетинговые инструменты: реклама в средствах массовой информации, участие в выставках и конференциях различного уровня, пресс-туры и другое. На основе изученной теоретической информации нами был сделан вывод, что одним из самых эффективных инструментов продвижения туристской дестинации являются интернет-технологии.

Интернет как источник информации намного опередил в популярности другие средства связи. По данным Международного союза электросвязи (МСЭ), ведущего учреждения Организации Объединенных Наций в области информационно-коммуникационных технологий, по данным на 2016 год в мире насчитывается 2,5 млрд. пользователей Интернета в развивающихся странах и около 1 млрд. - в развитых [3]. Эти цифры говорят о том, что интернет-аудитория поистине огромна.

Отличительными особенностями интернет-технологий, как инструмента продвижения, являются: широта охвата аудитории, возможность персонализированного подхода, постоянство функционирования, возможность оперативного размещения, обновления и удаления информации, одновременное использование сразу нескольких мультимедийный технологий (текст, аудио, видео, анимация и др.), относительно невысокая стоимость и другие.

Реализация маркетинговых целей продвижения товара и услуг в Интернете возможна с помощью различных технологий. В рамках изучения туристской индустрии Республики Мордовия, нами было проведено исследование по применению нескольких интернет-технологий как инструментов продвижения туристской дестинации. При этом учитывалась специфика дестинации, которая обусловлена в первую очередь тем, что туристская дестинация включает в себя множество взаимосвязанных элементов: 
ресурсы, используемые в рекреации и туризме, транспортная и сопутствующие виды инфраструктур, частные туристские фирмы, государственные учреждения, регулирующие деятельность в области туризма и другие. Во-вторых, специфику создают особенности финансирования проектов по продвижению дестинации, так как, в отличие от продвижения отдельных туристских фирм, основной источник финансов для регионального туризма - региональный бюджет, финансирование из частных источников крайне незначительно.

В результате исследования был отобран ряд интернет-технологий, наиболее эффективных, по нашему мнению, в качестве инструмента продвижения туристской дестинации.

Самым популярным и, в тоже время, эффективным инструментом продвижения территории и регионального туристского продукта в Сети Интернет является создание собственного сайта. В настоящее время активное распространение получает такой вид сайта, как Web-портал. Портал - сайт, организованный как системное многоуровневое объединение разных ресурсов и сервисов [2]. Web-портал, в отличие от сайта, предоставляет пользователям больший объем разнообразного контента, а также всевозможные интерактивные сервисы.

Портал как инструмент интернет-продвижения конкретного региона обретает новую форму в виде туристско-информационного портала. Туристско-информационный портал - это интерактивный проект, объединяющий актуальную туристскую информацию в наиболее удобном массовому пользователю формате.

Благодаря использованию на одной интернет-площадке нескольких интернеттехнологий, туристско-информационный портал выполняет одновременно ряд функций:

- объединение информации о туристских ресурсах региона, частных и государственных компаниях, работающих в сфере туризма, а также о проводимых в регионе мероприятиях на основе единой базы данных;

- охват значительно более широкой аудитории, как в России, так и за рубежом и, следовательно, преумножение количества потребителей туристских услуг;

- продвижение общего бренда туристской дестинации, а также отдельных брендов региона;

- повышение историко-культурной грамотности населения;

- осуществление обратной связи с туристами и заинтересованными сторонами;

- консультирование потенциальных потребителей туристских услуг;

- выполнение функции торговой площадки, например, для продажи билетов на местный общественный транспорт, туристских материалов: карт, буклетов, краеведческой и исторической литературы, сувениров.

Указанные выше функции ведут к достижению основных целей создания туристско-информационного портала - формированию позитивного имиджа и туристской привлекательности территории, повышению конкурентоспособности регионального туристского продукта и привлечению туристов в регион. Туристскоинформационный портал является основным представительством региона в интернетпространстве.

Кроме непосредственно туристско-информационного портала региона огромное значение в продвижении дестинации имеют порталы о путешествиях, объединяющие различные туристские направления. Преимущество данных интернет-площадок состоит 
в том, что, несмотря на разницу в требованиях к контенту, в большинстве своем информация размещается бесплатно.

Основными туристскими порталами в России являются: мультимедийный информационный ресурс о туристических возможностях регионов России «Добро пожаловать в Россию», Национальный туристический портал «Russia Travel», Национальный туристический портал России «RUSSIA JOURNEY», Информационный портал «Страна.гu» и другие.

Основная цель подобных проектов - продвижение отечественных турпродуктов на внутреннем и зарубежном рынках, укрепление имиджа России как туристской страны. Следует учесть, что большинство подобных интернет-порталов имеют версию на английском языке, что позволяет распространять информацию о туристской привлекательности региона и на иностранных пользователей Интернета.

Кроме российских интернет-площадок, активное использование для привлечения иностранных туристов получили зарубежные сайты о туризме. Например, портал «Wikitravel», позиционирующий себя как свободный интернет-путеводитель по всему миру, в рамках которого любой пользователь может бесплатно разместить статью о туристской достопримечательности или внести изменения в уже созданные статьи, сайт о путешествиях «Tripadvisor», где любой человек может оставить отзыв о туристском объекте или регионе и другие.

Важную нишу в интернет-маркетинге дестинации в настоящее время занимает SMM-продвижение (Social Media Marketing) или продвижение в социальных сетях. По данным международного статистического портала «Статиста» по состоянию на 2016 год число активных пользователей социальных сетей в мире составило около 2,34 млрд человек, к 2020 году прогнозируется рост пользователей до 2,95 млрд человек [5]. Важным показателем в пользу использования социальных сетей также можно считать частоту посещений и время, проведенное в аккаунах. В среднем, мировые интернетпользователи тратят около 109 минут в день на социальные сети.

Высокую эффективность социальных сетей как источника интернетпродвижения обуславливают не только огромный охват аудитории и высокая частота посещений, но и возможности данной интернет-технологии. На базе социальных сетей возможно размещение информационного контента в виде текста, аудио-, фото-, видеоматериалов, анимации и gif-изображений, проведение конкурсов и розыгрышей, создание приложений, игр, полезных утилит, форумов. Благодаря ранжированию участников социальных сетей по полу, возрасту, месту проживания и другим критериям появляется возможность более точного отбора целевой аудитории. Огромное значение для распространения информации имеет успешная реализация на базе социальных сетей вирусного маркетинга, реализуемого за счет создания взаимосвязанных ссылок, как между различными социальными сетями, так и между социальными сетями и официальным туристско-информационным порталом региона. Все эти преимущества при относительно невысокой стоимости создания и развития проектов делают социальные сети одним из самых востребованных и эффективных инструментов продвижения дестинации и регионального туристского продукта в настоящее время.

Основным способом СММ-продвижения является создание сообществ, пабликов, групп в социальных сетях. Выбор конкретных социальных сетей также зависит от желаемой целевой аудитории. Так, в России и странах СНГ самым 
популярным сайтом является ВКонтакте, а зарубежная Европа и США отдают предпочтение Facebook, Twitter, Instagram.

Огромным преимуществом для продвижения в социальных сетях туристского продукта региона имеет функция геопозиционирования, т. е. определение местонахождения пользователя или конкретного объекта. Фото- и видеоматериалы распространяются по социальным сетям с огромной скоростью, зачастую теряя ссылку на первоисточник. Именно поэтому геолокация позволяет пользователям определить, где именно сделана фотография или снят ролик. Кроме этого существуют социальные сети, отмечающие геопозиционирование как ключевую отличительную черту, например Foursquare.com. Данное приложение позволяет не только разместить информацию о туристских ресурсах региона, но и проводить различные акции для пользователей на базе конкретных туристских объектов.

Одной из старейших и эффективных интернет-технологий считается E-mail рассылка. Это весьма эффективный инструмент продвижения фирмы в Интернете, благодаря возможности использования адресной рассылки рекламно-информационного характера заинтересованным клиентам [1, стр. 152]. Однако в настоящее время люди спешат защитить себя от рекламной информации, которая неконтролируемым потоком поступает на их почтовые ящики. В связи с разработкой и внедрением различных программ против спама, усовершенствованием законодательства в сфере защиты интернет-пользователей, а также низкой восприимчивостью владельцев почтовых ящиков к входящим рекламным письмам, e-mail-продвижение несколько утратило эффективность. В связи с этим в настоящее время все большую популярность обретает доверительный маркетинг, реализуемый, в том числе, на базе e-mail-рассылки. Доверительный маркетинг представляет собой вид маркетинга, когда у представителей целевого рынка и посетителей веб-сайта спрашивают разрешение для отправки им на электронную почту информации на регулярной основе [4, стр.78].

Доверительный маркетинг обладает высокой эффективностью за счет желания пользователей получать информацию именно из данного источника, и, следовательно, выше вероятность более вдумчивого ее изучения и совершения дальнейших покупок/бронирований.

Таким образом, уровень развития туризма в конкретном регионе во многом зависит от того насколько потенциальный потребитель осведомлен о туристском потенциале региона и насколько привлекательным ему кажется региональный туристский продукт. В данных условиях особое значение приобретает стратегия продвижения дестинации на российском и международном рынках.

В настоящее время интернет-технологии являются одним из самых действенных инструментов продвижения территории и регионального туристского продукта. Это обусловлено не только преимуществами Сети Интернет как канала продвижения, но и спецификой самого объекта продвижения - дестинации. Однако в выборе конкретных интернет-технологий следует учитывать соотношение эффективности и понесенных затрат в рамках данного специфического объекта продвижения.

\section{Список литературы:}

1. Дунец А.Н. Проектирование и продвижение регионального туристского продукта: учебное пособие [Текст] / А.Н. Дунец // Алт. гос. техн. ун-т им. И.И. Ползунова. - Барнаул: Изд-во АлтГТУ, 2014. - 164 с. 
2. Словарь прикладной интернетики под. ред. С.А. Нехаева, Н.В. Кривошеина [Электронный pecypc] // PERFEKT.RU: словари, глоссарии, справочники, энциклопедии онлайн. - Режим доступа: http://www.perfekt.ru/dictionaries/netica.html.

3. ICT Facts and Figures 2016: report on 14th World Telecommunication/ICT Indicators Symposium (WTIS) [Текст], 21-23 November, Botswana, 2016. - 8 p.

4. Sweeney S. 101 ways to promote your tourism web site: filled with proven internet marketing tips, tools. [Текст] // Maximum Press, 2008. - 391 p.

5. The Statistics Portal [Электронный ресурс] // Statistics and facts about social media usage. - Режим доступа: https://www.statista.com/topics/1164/social-networks.

\title{
Юридические курсы как один из способов повышения правовой грамотности населения Нерюнгринского района
}

\author{
Кирикова Е.Н., студентка, \\ Нерюнгринский филиал \\ ГАПОУ РС (Я) «Алданский политехнический техникум», \\ 2. Нерюнгри \\ E-mail: kirikova1995@mai.ru
}

Научный руководитель: Чекалина Т.Н.

Каждый из нас, на протяжении жизни, постоянно сталкивается с вопросами юридического характера - заполнение бланков, заключение договоров, оформление завещания, наследства, расторжение брака и др. Но даже эти, казалось бы, повседневные вопросы, способны озадачить. А как часто люди страдают из-за правовой неграмотности? Приведу несколько случаев:

1. Информационный сайт г. Нерюнгри в материале «В г. Нерюнгри женщина попалась на уловку телефонных мошенников» (01.11.2016) сообщает, что у гражданки 1983 года рождения сняли с карты 48000 рублей. Она разместила объявление о продаже квартиры на Авито, и сообщила номер своей банковской карты потенциальному покупателю. После кражи денег мошенник перестал выходить на связь, гражданка обратилась в полицию. ${ }^{1}$

2. На сайте газеты «Индустрия Севера» был опубликован материал «Опять мошенники»(8.04.2016), в котором сообщалось, что 29 марта неизвестная женщина пришла в квартиру к гражданину 1934 года рождения, инвалиду по зрению, представилась старой знакомой и предложила помочь по хозяйству. Пенсионер беспрепятственно впустил «помощницу» в квартиру, так как она показалась ему знакомой. После ее визита мужчина обнаружил пропажу денежной суммы в размере 109000 рублей и обратился в полицию. ${ }^{2}$

\footnotetext{
${ }^{1}$ Информационный сайт г.Нерюнгри. Новостной материал: «В г.Нерюнгри женщина попалась на уловку телефонных мошенников» [Электронный ресурс] URL: http://nerungri.ru/news/orgs/16810

${ }^{2}$ Индустрия Севера. Новостной материал: «Опять мошенники» [Электронный ресурс] URL: http://www.indsever.ru/?module=articles\&action=view\&id=4102
} 